\title{
3: $161189331-161196508$
}

National Cancer Institute

\section{Source}

National Cancer Institute. 3:161189331-161196508. NCI Thesaurus. Code C42530.

Physical location of IL12A_Gene 